\title{
Attomolar-Level Ultrasensitive and Multiplex miRNA Detection enabled by a Nanomaterials Locally Assembled Microfluidic Biochip for Cancer Diagnosis
}

Yujin Chu ${ }^{\text {a }}$, Yakun Gao ${ }^{\text {a }}$, Wei Tang ${ }^{\text {b }}$, Le Qiang ${ }^{\text {a }}$, Yingkuan Han ${ }^{\text {a }}$, Jianwei Gao a , Yu Zhang ${ }^{\text {a }}$, Hong Liu c, Lin $\operatorname{Han}^{\mathrm{a}, *}$

${ }^{a}$ Institute of Marine Science and Technology, Shandong University, Qingdao, Shandong 266237, China;

${ }^{b}$ School of Basic Medical Science, Shandong University, Jinan, Shandong 250100, China;

${ }^{c}$ State Key Laboratory of Crystal Materials, Center of Bio \& Micro/Nano Functional Materials, Shandong University, Jinan, Shandong 250100, China.

* Corresponding author

E-mail address: hanlin@sdu.edu.cn (L.H.) 


\section{Table of concents}

Figure S1. Schematic fabrication process of double-layer microfluidic biosensing chip....................S4

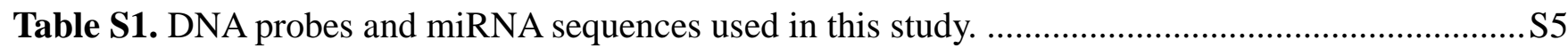

Figure S2. Work principle flow of the nanomaterials locally-assembled microfluidic biochip. ............S7

Figure S3. (a) TEM, (b) XRD, (c) Raman spectrum, and (d) Absorption spectrum of GO. (e) Raman and

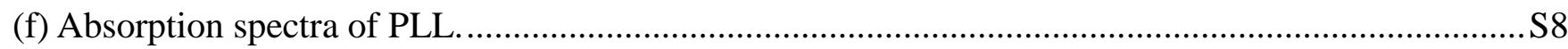

Figure S4. The surface morphology of glass slide and GO assembled glass slide............................S9

Figure S5. GO Raman scanning results of different positions on the glass substrate. .......................S10

Figure S6. FAM fluorescence group on the DNA probe Raman scanning results of different positions on

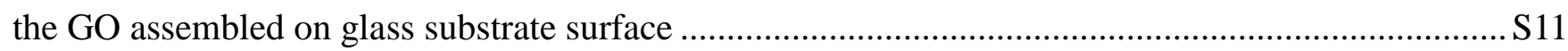

Figure S7. Design diagram of miRNA detection process verification. ............................................S12

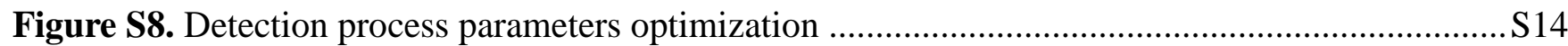

Figure S9. The detection result of different disease miRNAs using the five DNA probes and single- and

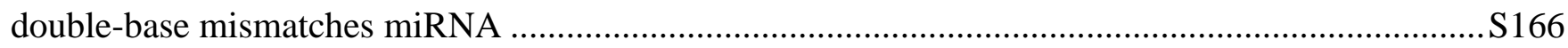

Figure S10. The sensitivity detection result of different miRNA ..............................................S168

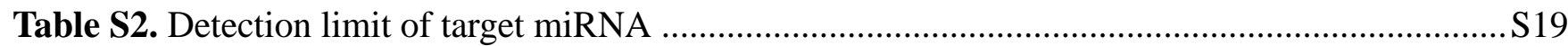

Table S3. Properties of different representative miRNA detection platform ...................................S20

Table S4. The miRNA concentration of each sample in TE buffer corresponding to Figure S11........S21

Table S5. Spiked miRNA concentrations in serum samples corresponding to Figure 5....................S22

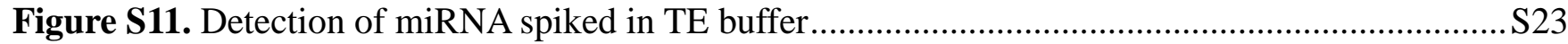

Figure S12. Experimental results of spiked miRNAs in serum samples as listed in Table S5 ............S24

Table S6. The recovery percent of the actual detection miRNA concentration in TE buffer and serum.

Table S7. The miRNA actual detected concentrations and relative deviations of each sample in TE buffer,

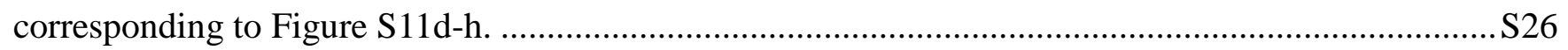

Table S8. The relative deviation between the actual detection concentration and theoretical concentration

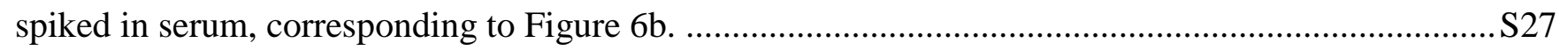

Figure S13. Detected fluorescence intensity of miRNA in healthy and patient serum .....................S28 
Figure S14. Detected concentrations of the miRNA biomarkers in serum samples from healthy persons

Figure S15. Detected concentrations of the miRNA biomarkers in serum samples from breast cancer patients..... S300 


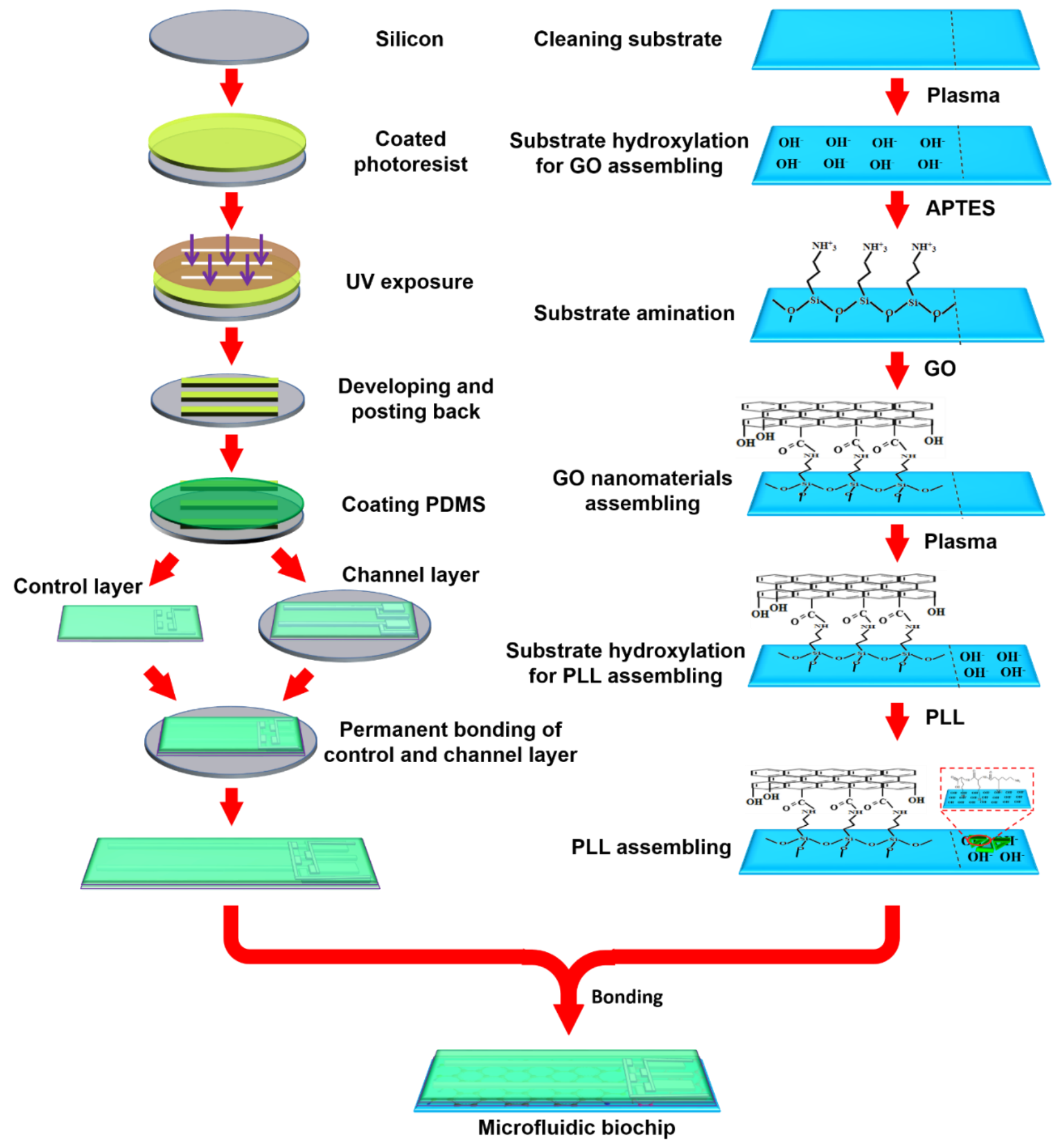

Figure S1. Schematic fabrication process of double-layer microfluidic biosensing chip. 
Table S1. DNA probes and miRNA sequences used in this study.

\begin{tabular}{|c|c|c|}
\hline Symbol & Description & Sequence (from $5^{\prime}$ to $3^{\prime}$ ) \\
\hline P-miR-125 & DNA probe for miR-125 & 5'-TCACAAGTTAGGGTCTCAGGGA (FAM)-3' \\
\hline $\operatorname{miR}-125$ & Target miR-125 & 5'-UCCCUGAGACCCUAACUUGUGA-3' \\
\hline P-miR-126 & DNA probe for miR-126 & 5'-CGCATTATTACTCACGGTACGA (FAM)-3' \\
\hline $\operatorname{miR}-126$ & Target miR-126 & 5'-UCGUACCGUGAGUAAUAAUGCG-3' \\
\hline P-miR-191 & DNA probe for miR-191 & 5'-CAGCTGCTTTTGGGATTCCGTTG (FAM)-3' \\
\hline miR-191 & Target miR-191 & 5'-CAACGGAAUCCCAAAAGCAGCUG-3' \\
\hline miR-191-S & Single-base mismatch miR-191 & 5'-CAACGGAAUCCGAAAAGCAGCUG-3' \\
\hline miR-191-D & Double-base mismatch miR-191 & 5'-CAACGGAAUGCGAAAAGCAGCUG-3' \\
\hline P-miR-155 & DNA probe for miR-155 & 5'-AACCCCTATCACGATTAGCATTAA (FAM)-3' \\
\hline miR-155 & Target miR-155 & 5'-UUAAUGCUAAUCGUGAUAGGGGUU-3' \\
\hline P-miR-21 & DNA probe for miR-21 & 5'-TCAACATCAGTCTGATAAGCTA (FAM)-3' \\
\hline $\operatorname{miR}-21$ & Target miR-21 & 5'-UAGCUUAUCAGACUGAUGUUGA-3' \\
\hline P-miR-1246 & DNA probe for miR-1246 & 5'-CCTGCTCCAAAAATCCATT (FAM)-3' \\
\hline $\operatorname{miR}-1246$ & Target miR-1246 & 5'-AAUGGAUUUUUGGAGCAGG-3' \\
\hline P-miR-200c & DNA probe for miR-200c & 5'-CCTCCATCATTACCCGGCAGTAT (FAM)-3' \\
\hline miR-200c & Target miR-200c & 5'-AUACUGCCGGGUAAUGAUGGAGG-3' \\
\hline P-Let-7b & DNA probe for Let- $7 b$ & 5'-CAGGGAAGGCAGTAGGTTGTATA (FAM)-3' \\
\hline Let-7b & Target Let- $7 \mathrm{~b}$ & 5'-UAUACAACCUACUGCCUUCCCUG-3' \\
\hline P-miR-200b & DNA probe for miR-200b & 5'-CGTGCAGGGCTCCGCCGTCATCA (FAM)-3' \\
\hline miR-200b & Target miR-200b & 5'-UGAUGACGGCGGAGCCCUGCACG-3' \\
\hline P-miR-1298-3p & DNA probe for miR-1298-3p & 5'-GTTCAGTCAGTTGCCCAGATG (FAM)-3' \\
\hline $\operatorname{miR}-1298-3 p$ & Target miR-1298-3p & 5'-CAUCUGGGCAACUGACUGAAC-3' \\
\hline P-miR-1298-5p & DNA probe for miR-1298-5p & 5'-TACATCTGGACAGCCGAATGAA (FAM)-3' \\
\hline $\operatorname{miR}-1298-5 p$ & Target miR-1298-5p & 5'-UUCAUUCGGCUGUCCAGAUGUA-3' \\
\hline
\end{tabular}


P-miR-4484 DNA probe for miR-4484

$\operatorname{miR}-4484$

Target miR-4484

DNA probe for miR-4732-6p

$\operatorname{miR}-4732-6 \mathrm{p}$
5'-TGGGCTGGGCTCATTTCATTTT (FAM)-3'

5'-AAAAUGAAAUGAGCCCAGCCCA-3'

5'-AGCTTCCTGCTCCCTGCTCTACA (FAM)-3'

5'-UGUAGAGCAGGGAGCAGGAAGCU-3' 
(a)

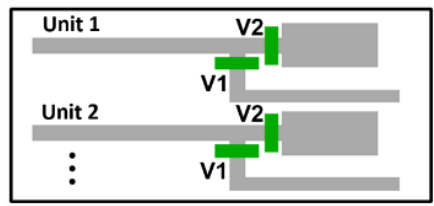

Original status

(f)

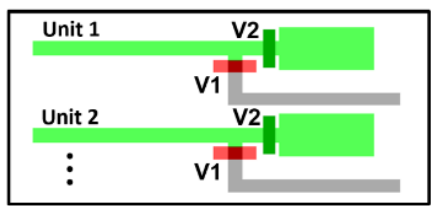

DNA-miRNA complex collection

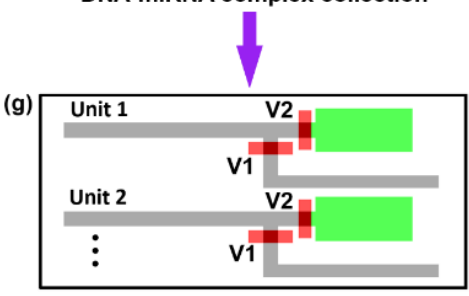

DNA-miRNA complex reaction with PLL

Empty flow and chamber

miRNA-DNA complex

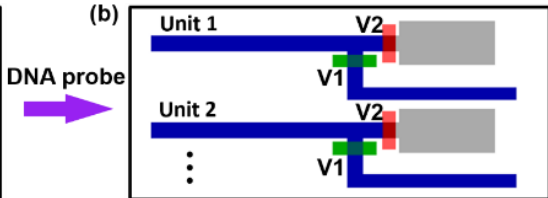

DNA probe flushing into reaction channel

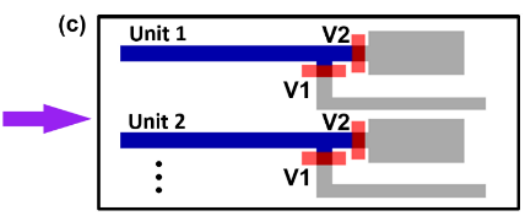

DNA probe incubation

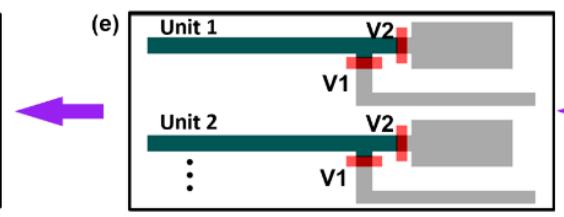

DNA and miRNA hybridization

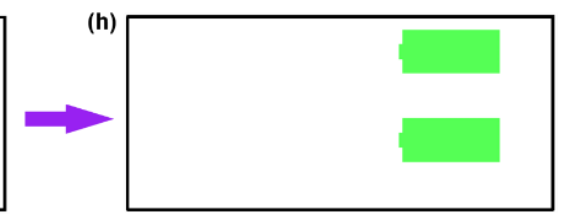

FL signal detection

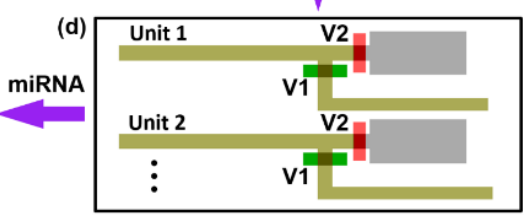

Extra DNA probe removing

Close valve

DNA probe

PBS solution

Target miRNA

Target miRNA

Figure S2. Work principle flow of the nanomaterials locally-assembled microfluidic biochip. 
TEM image of GO nanosheets in Figure S3a indicates the size of nanosheets in a range of 50-200 $\mathrm{nm}$. To understand the interlayer spacing of GO nanosheets, XRD was carried out and the results are shown in Figure S3b. The $\left(\begin{array}{lll}0 & 0 & 1\end{array}\right)$ crystal plane of GO have a strong and sharp peak at $10.0^{\circ}$, corresponding to layer spacing of $0.90 \mathrm{~nm}$. The Raman spectrum of GO in Figure S3c shows two representative peaks at $1349 \mathrm{~cm}^{-1}$ and $1601 \mathrm{~cm}^{-1}$, and the peak at $1601 \mathrm{~cm}^{-1}$ is common in all $\mathrm{sp}^{2}$ carbon forms, and formed from stretching the C-C bond. The absorption spectroscopy of GO solution in Figure S3d indicates the maximum absorption peak at $235 \mathrm{~nm}$ assigned to the $\pi \rightarrow \pi^{*}$ transition of the $\mathrm{C}-\mathrm{C}$ bonds, and the shoulder around $300 \mathrm{~nm}$ corresponding to the $\mathrm{n} \rightarrow \pi^{*}$ transition of $\mathrm{C}=\mathrm{O}$ bonds. The Raman and absorption spectrum of PLL detected by SERS and Microplate reader were shown in Figure S3e and S3f, respectively. PLL appears five representative Raman peaks at $2923 \mathrm{~cm}^{-1}, 2868 \mathrm{~cm}^{-1}, 1667 \mathrm{~cm}^{-1}, 1443 \mathrm{~cm}^{-1}$, and $1317 \mathrm{~cm}^{-1}$, and the $2923 \mathrm{~cm}^{-1}$ and $2868 \mathrm{~cm}^{-1}$ peaks represent the characteristic of hydrocarbon aliphatic bands. The peaks at $1667 \mathrm{~cm}^{-1}$ shows the asymmetric stretching of the COO- group. And the $1443 \mathrm{~cm}^{-1}$ peak could be described as deformations of $\mathrm{NH}_{3}{ }^{+}$species, while the $1317 \mathrm{~cm}^{-1}$ peak indicates $\mathrm{NH}_{2}$ and $\mathrm{CH}_{2}$ bending modes coupled to $\mathrm{CH}_{2}$ twisting vibrations. The maximum absorption of PLL appears at $220 \mathrm{~nm}$ which indicates that assembled PLL will not affect fluorescence detection of FAM molecules on PLL substrate excited by $488 \mathrm{~nm}$ laser.
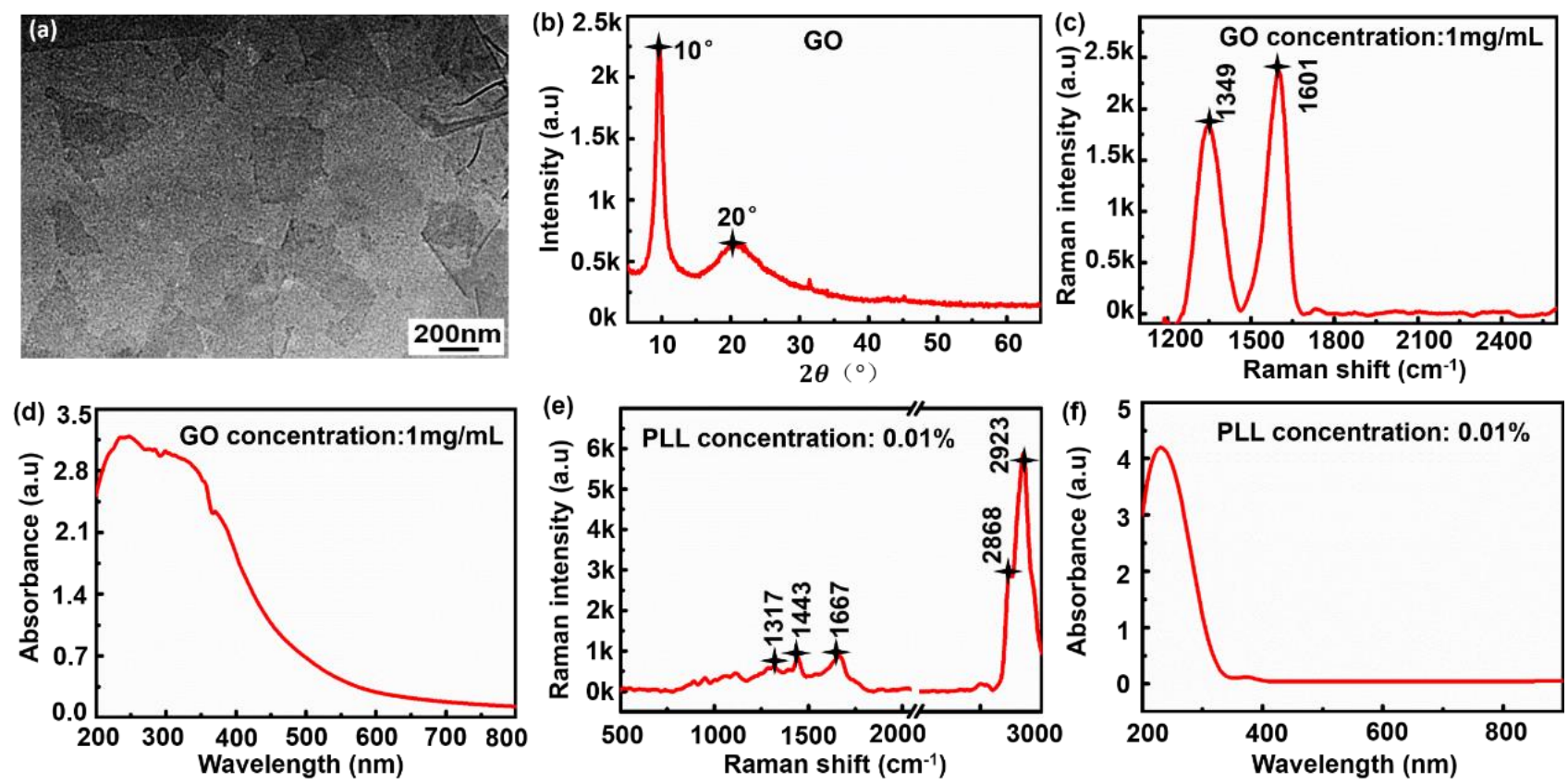

Figure S3. (a) TEM, (b) XRD, (c) Raman spectrum, and (d) Absorption spectrum of GO. (e) Raman and (f) Absorption spectra of PLL. 


\section{Characteristic of surface morphology of GO assembled on glass substrate}

Using the methods of GO assembled on glass slide of Nanomaterials locally-assembling on substrate in Experimental and Methods section, GO is assembled on a cleaned glass substrate. The Smart SPM AFM system was used to measure surface morphology of GO assembled glass slide, as shown in Figure S4. It can be seen from Figure S4a that the surface roughness of cleaned glass slide is higher, with a value of $0.9006 \mathrm{~nm}$. Figure S4b shows the surface morphology after GO assembling which was smoothed slightly.
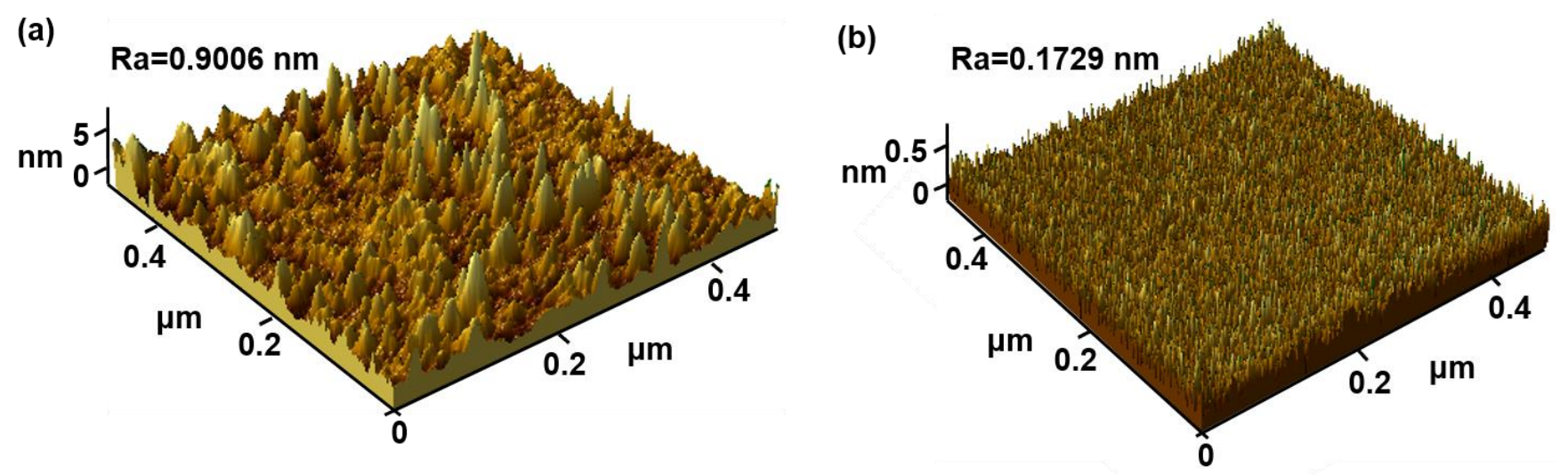

Figure S4. The surface morphology of (a) glass slide and (b)GO assembled substrate 


\section{Characteristic of Raman mapping of the GO assembled on glass substrate}

To characterize the distribution of GO assembled glass substrate surface, we scanned 12 random positions on the substrate using Renishaw inVia Raman microscope, as shown in Figure S5. The color change from black to red in the mapping indicates the representative peak intensity change of GO assembled glass substrate from less to more. The relative standard deviation all over the substrate is less than $1 \%$, which indicates that GO is uniformly assembled on the glass substrate.
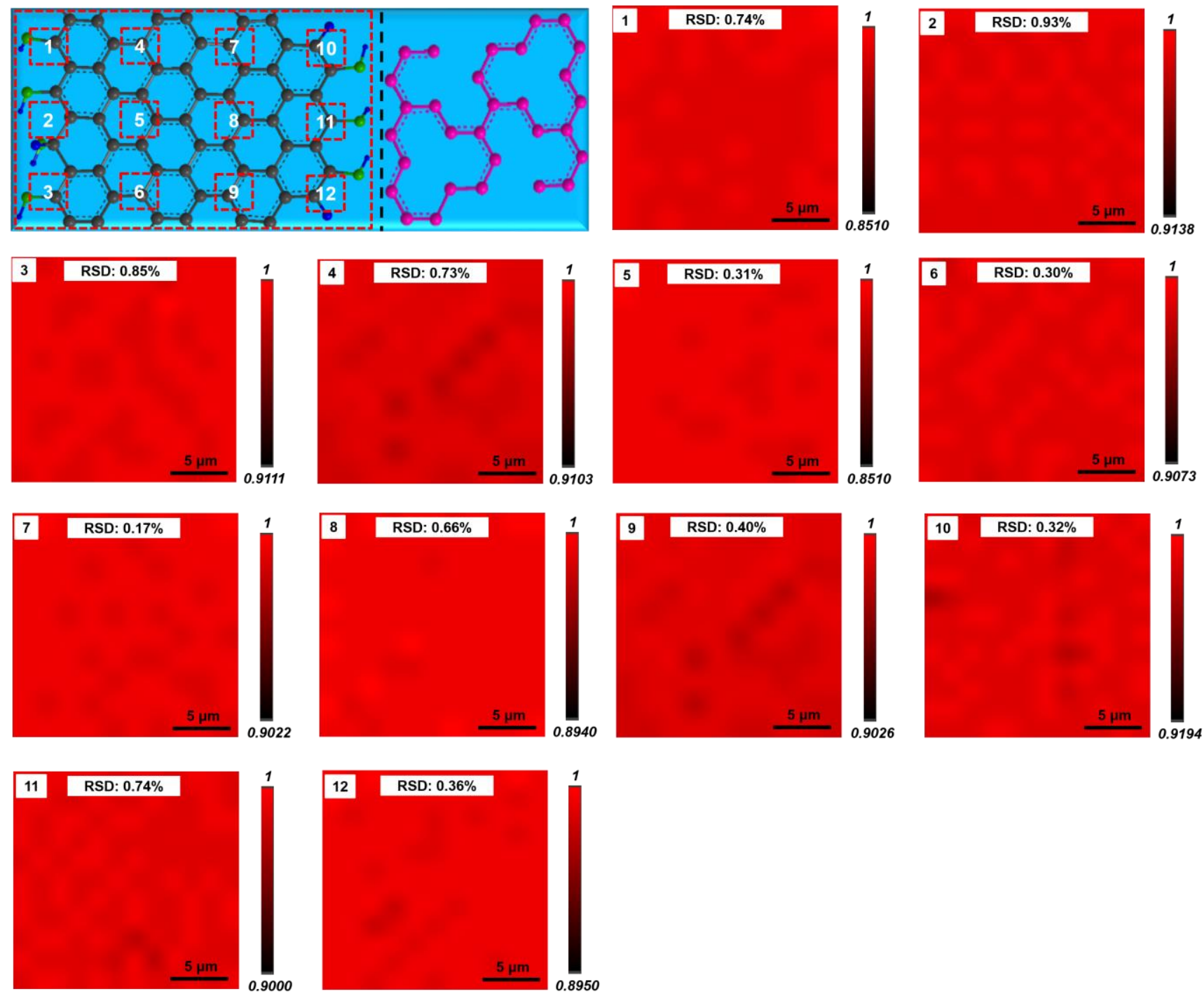

Figure S5. GO Raman scanning results of 12 random positions on the glass substrate. The scanning range is $20 \times 20 \mu \mathrm{m}^{2}$. 


\section{Distribution of DNA probe loaded on GO surface}

The capture yield of DNA probes on the substrate has an important influence on the sensitivity and accuracy of miRNA detection. In order to characterize the capture yield of the DNA probe on the GO assembled on substrate, Raman scanning of the FAM fluorescence group labled on the probe was performed, as shown in Figure S6. The number of DNA probe immobilized on GO surface increases with the color change from black to green in the mapping. The relative standard deviation is all less than $1 \%$, which indicates that the DNA probe was uniformly immobilized on the GO surface.
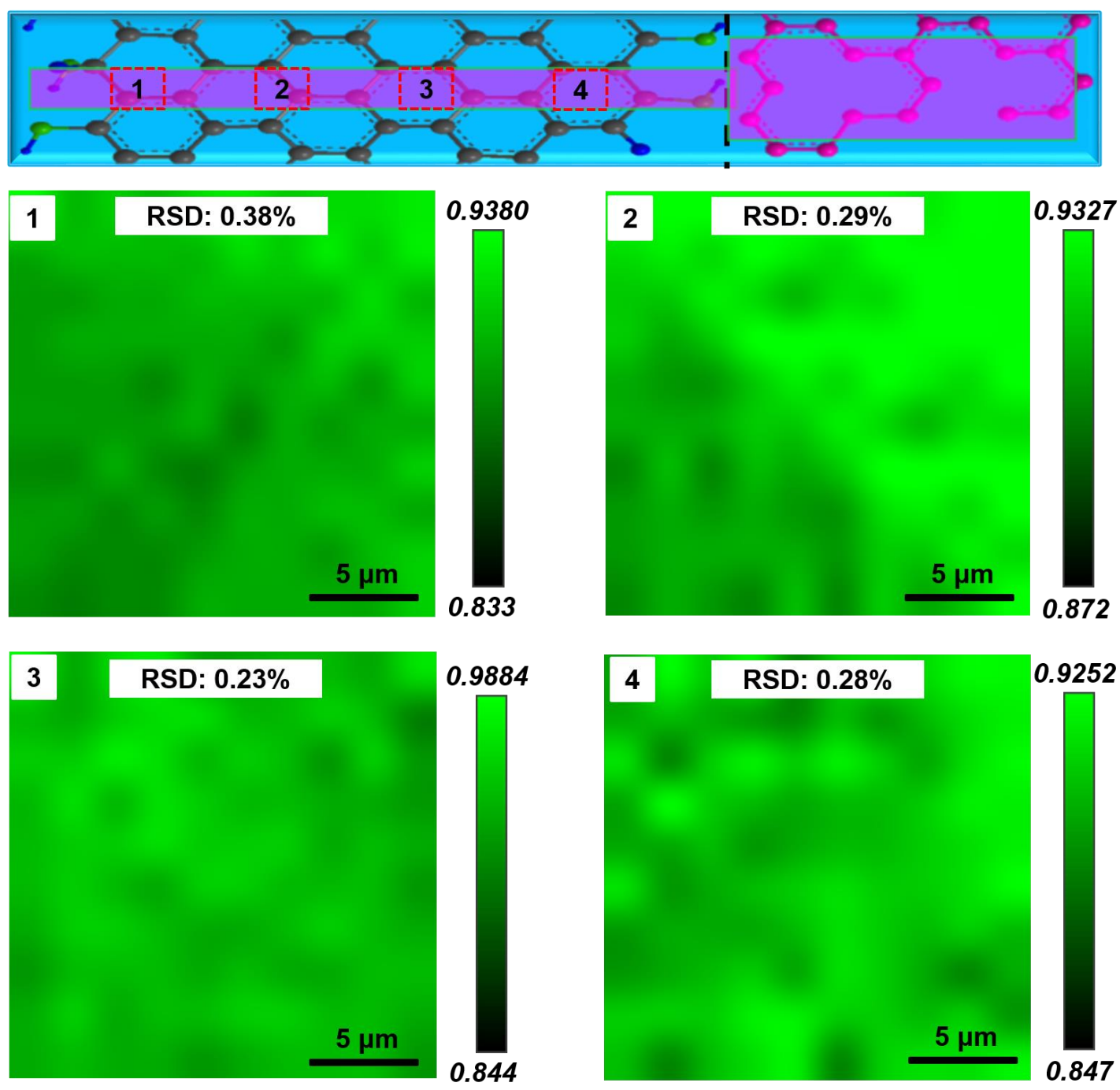

Figure S6. Representative peak intensity distribution of FAM labeld on probe from scanned Raman spectra of four random positions on GO surface after DNA probe immobilization. Each scanning area is $20 \times 20 \mu \mathrm{m}^{2}$. 


\section{Detection process verification}

Firstly, the DNA probe is added to well \#2 and \#3, and TE buffer is loaded into well \#1 on GO nanosheets assembled area, and Raman tests were performed for all three wells. Next, TE buffer and miRNAs were loaded into well \#2 and \#3 on GO substrate, respectively, and incubated for 35 minutes. Then, the solution in well \#2 and \#3 was moved to well \#2' and \#3' on PLL substrate, respectively, and incubated on PLL for 25 minutes. Finally, the fluorescence and FAM Raman spectra of well \#2' and \#3' on PLL substrate were detected by GenePix 4400 and Raman, respectively.

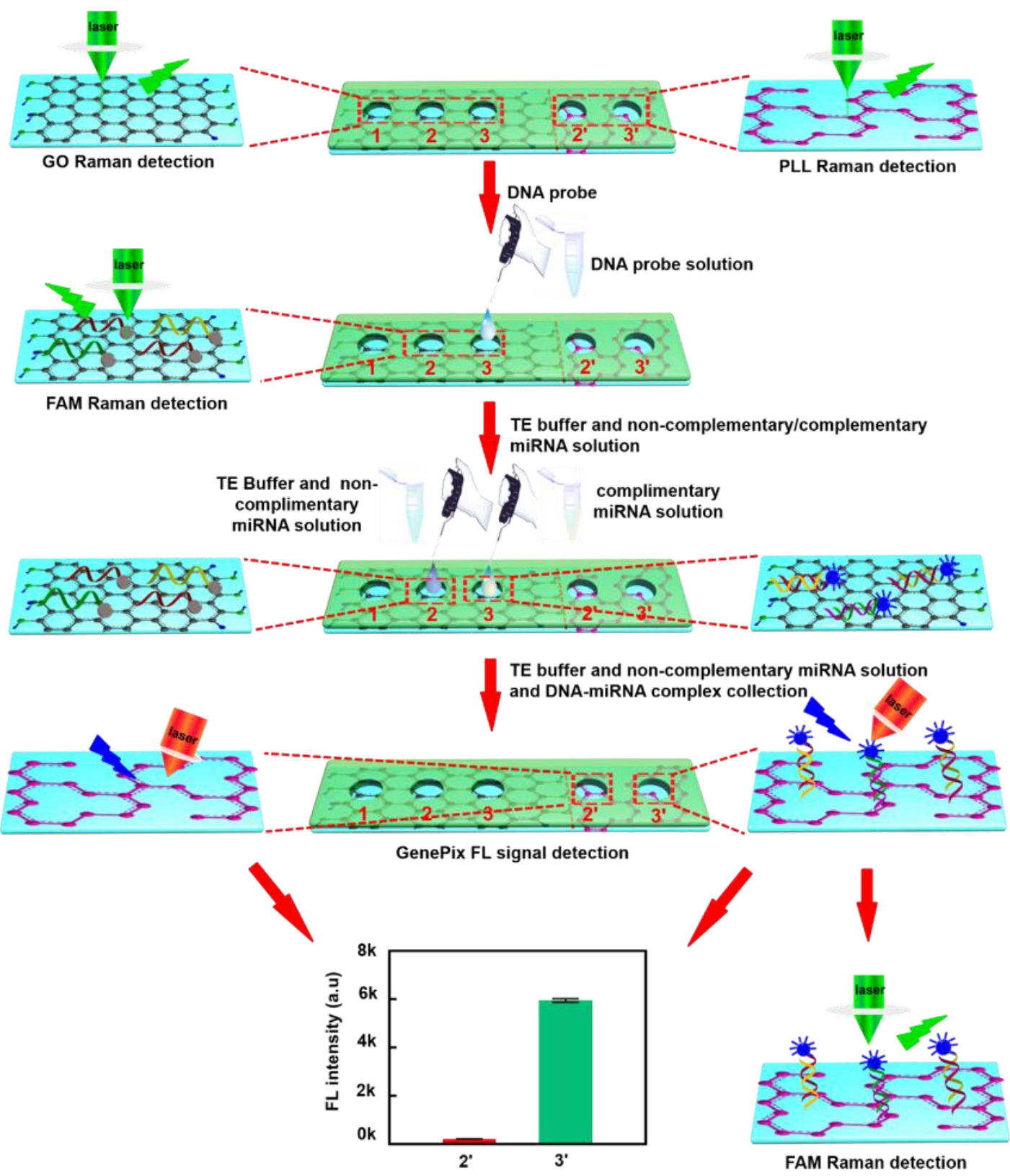

Figure S7. Design diagram of miRNA detection process verification. 


\section{Detection process Optimization}

To obtain appropriate DNA probe concentration during the immobilization on GO assembled substrate, probe concentration of $10^{-9}-10^{-4} \mathrm{M}$ is loaded into reaction channel, $10^{-9} \mathrm{M}$ target miRNA is applied to hybridize with DNA probe after probe immobilization and channel cleaning. As shown in Figure S8a, the detected fluorescence intensity of DNA-miRNA complex increases with probe concentration and achieves maximum value at $10^{-4} \mathrm{M}$. As a result, $10^{-4} \mathrm{M}$ DNA probe is used to conjugate with GO assembled substrate in the following miRNA detection. To achieve optimized incubation time between DNA probe and GO assembled substrate, $10^{-4} \mathrm{M}$ probe is loaded into reaction channel and incubation different time, and then $10^{-9} \mathrm{M}$ target miRNA is introduced. The fluorescence intensity of DNA-miRNA complex increases with incubation time and reaches the maximum value at 35 minutes, as shown in Figure S8b. Therefore, 35 minutes is used as an optimized incubation time between probe and GO assembled substrate. It is extremely important for the subsequent target miRNA detection whether extra probe is cleaned out since PLL absorbs both DNA probe and DNA-miRNA complex, and DNA probe labeled with FAM contributes to the final fluorescence intensity. Figure S8c shows that there is negligible DNA residue after flushing 5 times, in which the $6^{\text {th }}$ flushing liquid is collected by detection chamber. Therefore, the biochip was flushed 5 times after DNA probes immobilization and ready for miRNA detection. Hybridization time between target miRNA and DNA probe is the main consuming time of miRNA detection, and experimental results indicate miRNA hybridizes with DNA adequately in 25 minutes, as shown in Figure S8d from 5 different breast cancer miRNA biomarkers. Figure S8e implies that DNA-miRNA complex is completely collected in detection chamber after 5 times PBS flushing, which is consistent with the results of extra DNA probe removing after DNA probe immobilization in Figure S8c. Finally, the immobilization time of DNA-miRNA complex in detection chamber is optimized as shown in Figure S8f. The fluorescence intensity of DNA-miRNA complex reaches maximum and stable status after 10 minutes immobilization in detection chamber. Therefore, DNA-miRNA complex collection time in detection chamber is set as 10 minutes. 

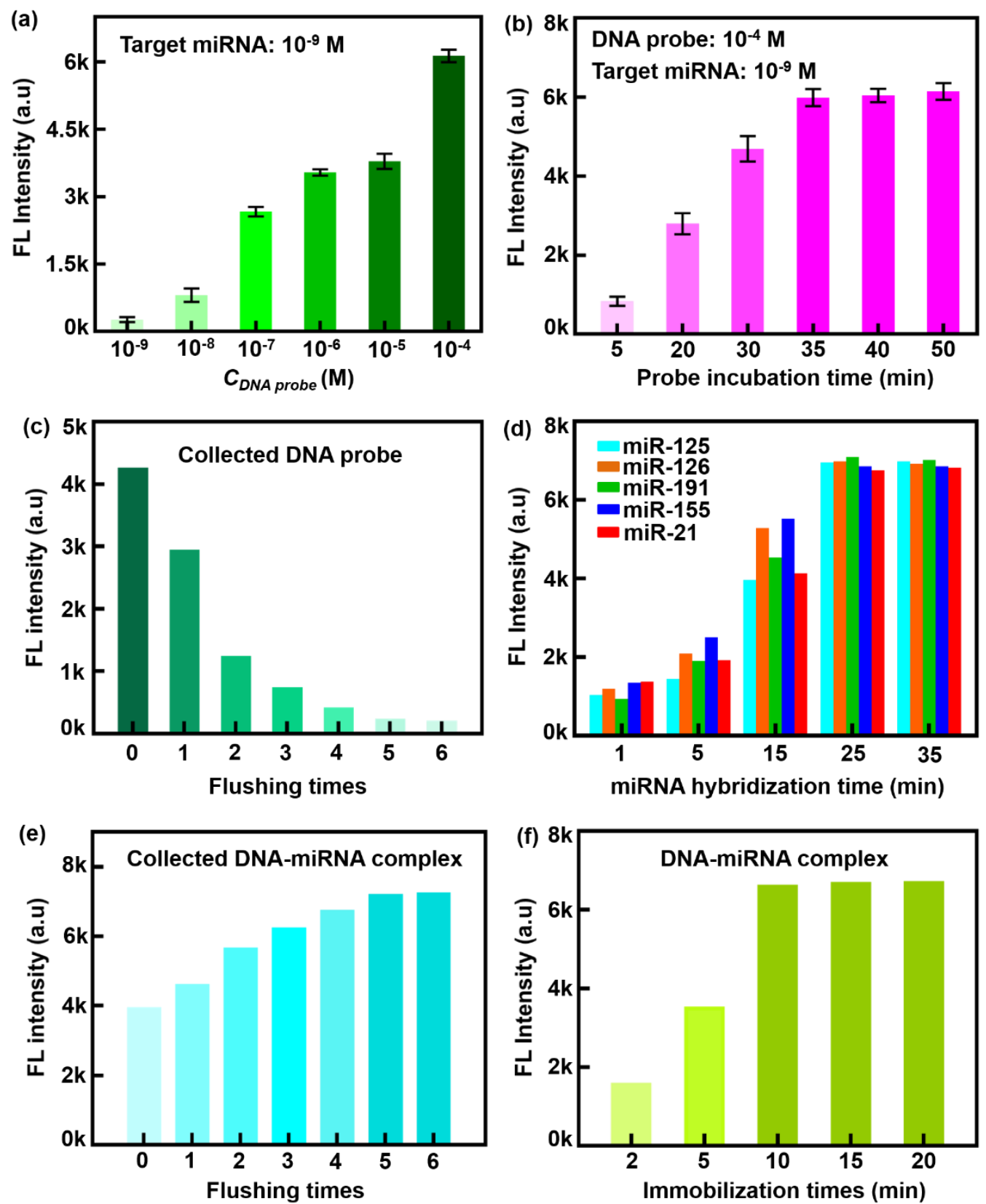

Figure S8. Detection process parameters optimization. (a) DNA probe concentration. (b) DNA probe incubation time in reaction microchannel. (c) Extra DNA probe removing through different PBS flushing times. (d) Fluorescence intensity of collected DNA-miRNA complex at different hybridization time for target miRNAs. (e) Fluorescence intensity of collected DNA-miRNA complex dependence on PBS flushing times. (f) The DNA-miRNA complex immobilization time in detection chamber. Note, the error bars in (a) and (b) are the difference between Mean value and standard deviation from 3 times tests. The error bars are derived by equation $\sqrt{\frac{1}{N} \sum_{i=1}^{N}\left(x_{i}-\text { Mean }\right)^{2}}, \mathrm{~N}=3$. 
To verify the specificity of the five DNA probes in the experiment, complementary sequences corresponding to the five DNA probes were used for mutual varication, as shown in Figure 3a. Further, in order to verify microfluidic biochip detection platform specificity, we used the five DNA probes in the experiment to detect the other diseases target miRNAs, such as regulating tumor initiation and metastasis of miR-1246 ${ }^{1}$ and acting as a negative regulator of epithelial-mesenchymal transition (EMT) of miR$200 c^{2}$ in lung cancer, having the oncogenic functional of miR-200b and Let-7b in ovarian cancer ${ }^{3,4}$, inhibiting glioma cells proliferation, migration and invasion of miR-1298-3p and miR-1298-5p in glioma $^{5,6}$, up-regulated (miR-4484) and down-regulated (miR-4732-5p) miRNAs in nipple discharge of breast cancer patient ${ }^{7,8}$. The detection result is shown in Figure S9a-e. The result shown that for five DNA probes, the complete complementary miRNAs showed high fluorescence intensity, whereas for other disease miRNAs showed very low fluorescence intensity. The fluorescence intensity of complementary miRNAs was 20 times higher than that of non-complementary miRNAs, and the fluorescence valve of non-complementary is close to the fluorescence valve detected washing 5 times in Figure S8c. The result indicates prominent specificity between DNA probes and target miRNAs, and the biochip detection platform has excellent specificity. In order to evaluate the specificity of the nanomaterials locally-assembled microfluidic biochip miRNA detection platform, single- and doublebase mismatched miR-191 was selected as the target miRNA, as shown in Figure S9f. The fluorescence detection result shown that the fluorescence intensity of single- and double-base mismatched miRNAs was 6 times lower than that of complementary miRNAs respectively. The detection present excellent specificity of detecting homologous sequence miRNAs. 

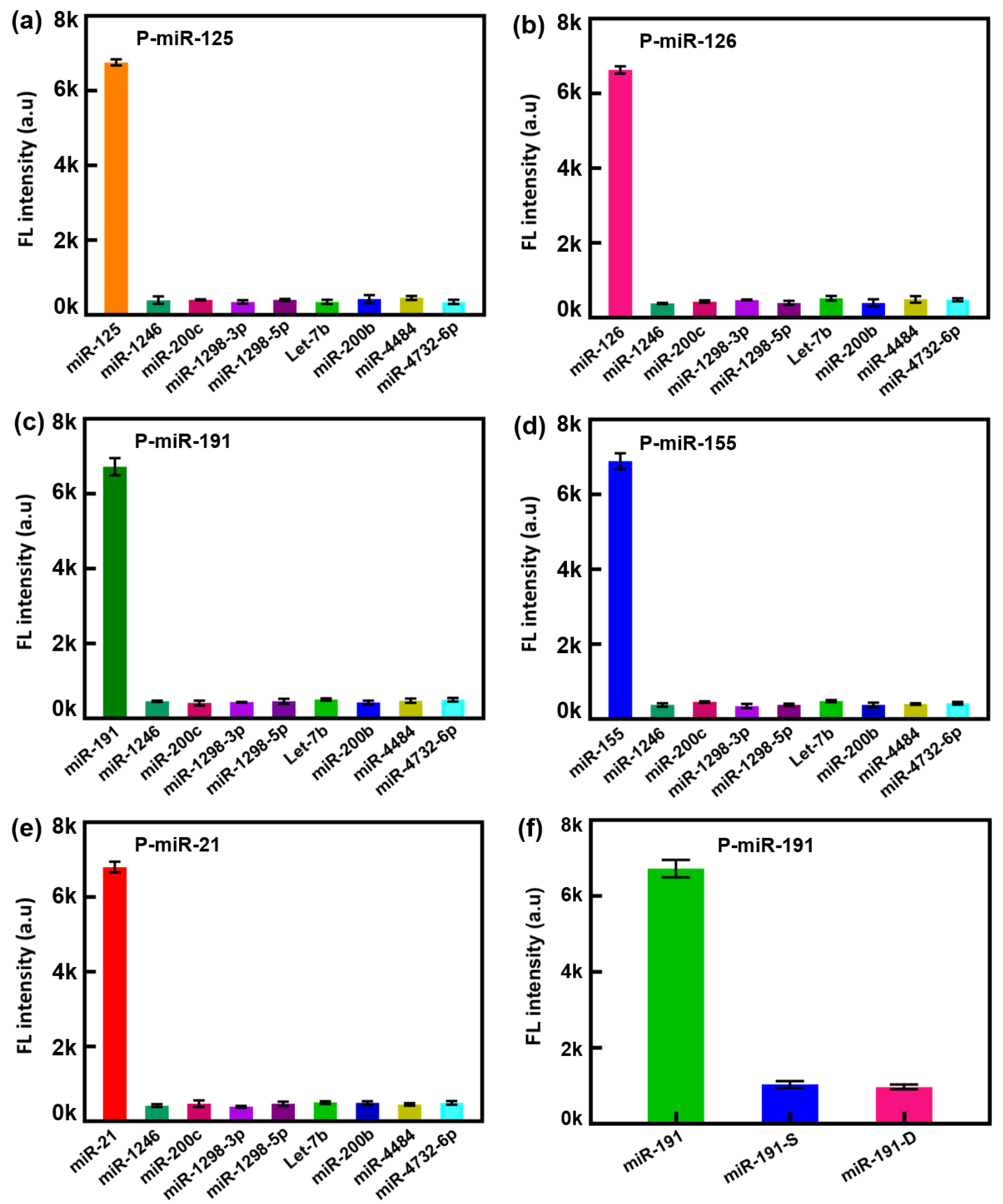

Figure S9. (a)-(e) The detection result of different disease miRNAs using the five DNA probes. (f) The detection result of homologous sequence miRNA using P-miR-191. The miR-191-S and miR-191-D represents single- and double-base mismatches miRNA, respectively. 
In order to verify the universality of the biochip detection platform, we selected other diseases miRNAs for sensitivity detection, such as lung cancer, ovarian cancer, glioma and breast cancer exosomes. According to the optimization results of different DNA probes concentration in Figure S8a, the concentration of each DNA probe was $100 \mu \mathrm{M}$, and the concentration range of the detected target miRNA was $10^{-13}-10^{-8} \mathrm{M}$. The detect results are shown in Figure S10. For each target miRNAs, when the concentration varies from $10^{-13}-10^{-8} \mathrm{M}$, the fluorescence intensity increases with concentration and presents a linear relationship with concentration in log scale. It can be seen that the microfluidic biochip detection platform has the similar quantification relationship in the range of $10^{-13}-10^{-8} \mathrm{M}$ for more miRNAs for other cancers, which indicates the excellent universality of the biochip. 

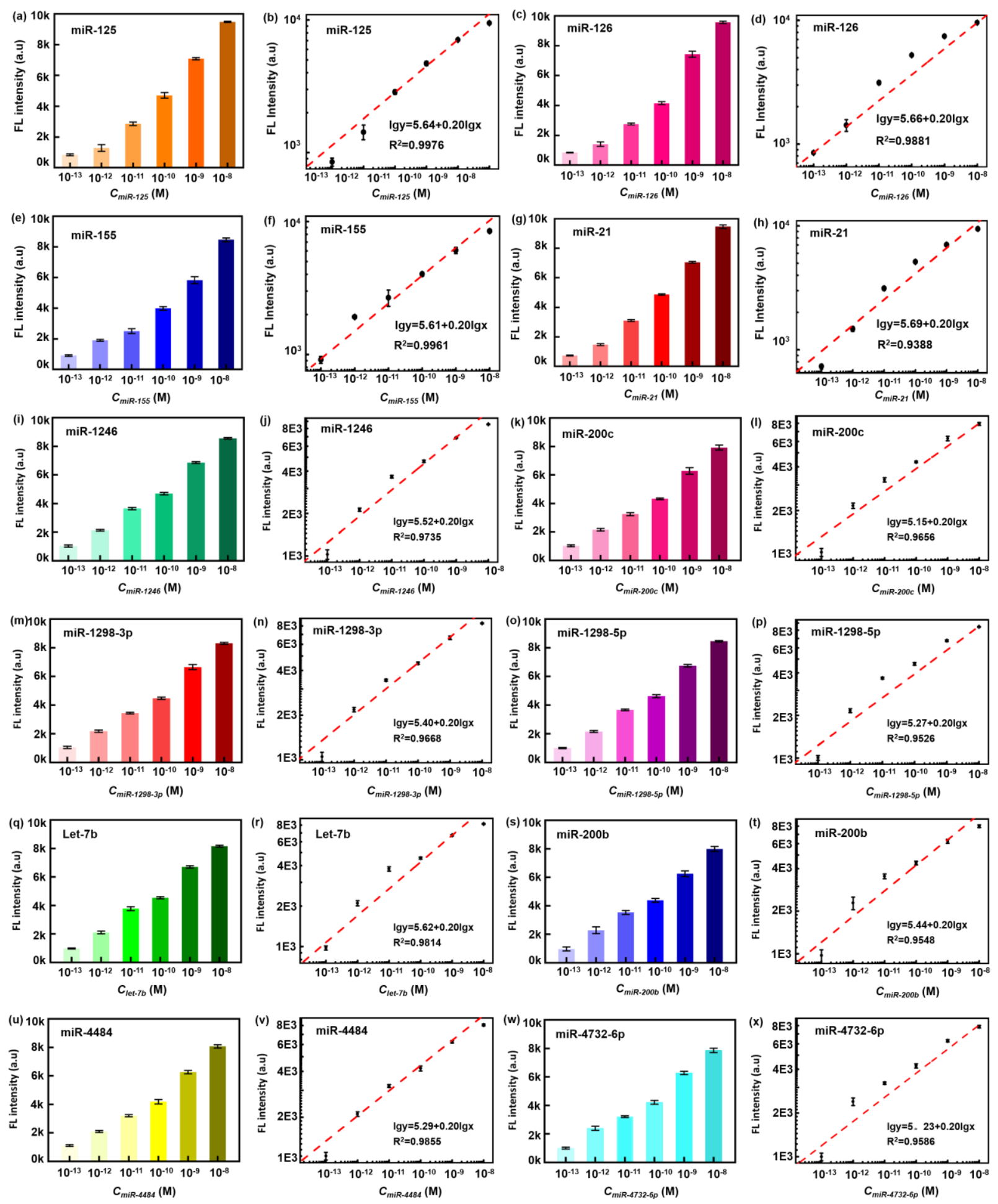

Figure S10. Sensitivity of the microfluidic biochip. The fluorescence intensity corresponding to different concentration of miRNAs. The linear relationship between fluorescence intensity and the concentration of target miRNAs. All the experiments are repeated for 3 times. The error bars are derived from equation $\sqrt{\frac{1}{N} \sum_{i=1}^{N}\left(x_{i}-\text { Mean }\right)^{2}}, \mathrm{~N}=3$. 
Table S2. Detection limit of target miRNA

\begin{tabular}{cc}
\hline miRNA & miR-191 \\
\hline Method 1 & $\mathrm{y}=537.2+1.681 \times 10^{19} \mathrm{x}$ \\
Average background (a.u) & 205 \\
LOD (aM) & 1.41 \\
Method 2 & $\lg =5.25+0.14 \mathrm{x}$ \\
LOD (aM) & 0.146 \\
\hline
\end{tabular}


Table S3. Properties of different representative miRNA detection platform

\begin{tabular}{|c|c|c|c|c|c|c|}
\hline $\begin{array}{l}\text { Detection } \\
\text { method }\end{array}$ & MiRNA & Linear range & $\begin{array}{c}\text { Detection } \\
\text { limit }\end{array}$ & Detection time & $\begin{array}{l}\text { Sample } \\
\text { volume }\end{array}$ & Ref. \\
\hline $\begin{array}{l}\text { Electrochemi } \\
\text { cal } \\
\text { nanobiosens } \\
\text { or }\end{array}$ & $\operatorname{miR}-155$ & $2 \mathrm{fM}-8 \mathrm{pM}$ & $0.6 \mathrm{fM}$ & $1 \mathrm{~h}$ & - & 9 \\
\hline $\begin{array}{l}\text { Electrochemi } \\
\text { cal detection }\end{array}$ & $\begin{array}{c}\text { miR-7857 } \\
\text { miR-378 } \\
\text { miR-92 miR- } \\
205\end{array}$ & $\begin{array}{c}1 \mathrm{pM}-1.5 \\
\mathrm{nM}\end{array}$ & $0.48 \mathrm{pM}$ & - & $20 \mu \mathrm{L}$ & 10 \\
\hline $\begin{array}{l}\text { DNA- } \\
\text { AuNPs } \\
\text { SERS }\end{array}$ & miR-21 & $1 \mathrm{nM}-1 \mathrm{pM}$ & $0.12 \mathrm{pM}$ & - & $4 \mu \mathrm{L}$ & 11 \\
\hline $\begin{array}{l}\text { FET- } \\
\text { biosensor }\end{array}$ & Let-7b & $\begin{array}{c}20 \mathrm{aM}-200 \\
\mathrm{fM}\end{array}$ & $600 \mathrm{zM}$ & $1 \mathrm{~h}$ & - & 12 \\
\hline $\begin{array}{l}\text { microfluidic/ } \\
\text { electrochemi } \\
\text { luminescenc } \\
\mathrm{e}\end{array}$ & miR-143 & $0-1.2 \mu \mathrm{M}$ & $1.5 \mathrm{fM}$ & - & $1.8 \mu \mathrm{L}$ & 13 \\
\hline $\begin{array}{l}\text { microfluidic } \\
\text { chip }\end{array}$ & $\begin{array}{c}\operatorname{miR}-21 \\
\operatorname{miR}-126\end{array}$ & $0.1 \mathrm{nM}-1 \mu \mathrm{M}$ & $\begin{array}{c}6.069 \mathrm{fM} \\
23.817 \mathrm{fM}\end{array}$ & $5 \mathrm{~min}$ & $100 \mu \mathrm{L}$ & 14 \\
\hline $\begin{array}{l}\text { GO/PLL } \\
\text { locally- } \\
\text { assembled } \\
\text { microfluidic } \\
\text { chip }\end{array}$ & $\begin{array}{c}\operatorname{miR}-125 \\
\text { miR-126 } \\
\text { miR-191 } \\
\text { miR-155 } \\
\text { miR-21 }\end{array}$ & $\begin{array}{l}0.1 \mathrm{pM}-10 \\
\mathrm{nM} \\
1 \mathrm{aM}-10 \mathrm{fM}\end{array}$ & $\begin{array}{c}1 \mathrm{fM} \\
0.146 \mathrm{aM}\end{array}$ & $\begin{array}{l}35 \min \\
75 \min \end{array}$ & $2 \mu \mathrm{L}$ & This work \\
\hline
\end{tabular}


Table S4. The miRNA concentration of each sample in TE buffer corresponding to Figure S11.

\begin{tabular}{cccccc}
\hline & $\begin{array}{c}\text { miR-125 } \\
\text { concentration } \\
(\mathrm{M})\end{array}$ & $\begin{array}{c}\text { miR-126 } \\
\text { concentration } \\
(\mathrm{M})\end{array}$ & $\begin{array}{c}\text { miR-191 } \\
\text { concentration } \\
(\mathrm{M})\end{array}$ & $\begin{array}{c}\text { miR-155 } \\
\text { concentration } \\
(\mathrm{M})\end{array}$ & $\begin{array}{c}\text { miR-21 } \\
\text { concentration } \\
(\mathrm{M})\end{array}$ \\
\hline Sample 1 & $1 \times 10^{-13}$ & $1 \times 10^{-11}$ & $1 \times 10^{-11}$ & $1 \times 10^{-9}$ & $1 \times 10^{-9}$ \\
Sample 2 & $1 \times 10^{-11}$ & $1 \times 10^{-9}$ & $1 \times 10^{-9}$ & $1 \times 10^{-13}$ & $1 \times 10^{-13}$ \\
Sample 3 & $1 \times 10^{-9}$ & $1 \times 10^{-13}$ & $1 \times 10^{-13}$ & $1 \times 10^{-11}$ & $1 \times 10^{-11}$ \\
\hline
\end{tabular}


Table S5. Spiked miRNA concentrations in serum samples corresponding to Figure 5.

\begin{tabular}{cccccc}
\hline & $\begin{array}{c}\text { miR-125 } \\
(\mathrm{M})\end{array}$ & $\begin{array}{c}\text { miR-126 } \\
(\mathrm{M})\end{array}$ & $\begin{array}{c}\text { miR-191 } \\
(\mathrm{M})\end{array}$ & $\begin{array}{c}\text { miR-155 } \\
(\mathrm{M})\end{array}$ & $\begin{array}{c}\text { miR-21 } \\
(\mathrm{M})\end{array}$ \\
\hline Sample 1 & $1 \times 10^{-8}$ & $1 \times 10^{-9}$ & $1 \times 10^{-10}$ & $1 \times 10^{-11}$ & $1 \times 10^{-8}$ \\
Sample 2 & $1 \times 10^{-9}$ & $1 \times 10^{-10}$ & $1 \times 10^{-11}$ & $1 \times 10^{-8}$ & $1 \times 10^{-9}$ \\
Sample 3 & $1 \times 10^{-10}$ & $1 \times 10^{-11}$ & $1 \times 10^{-8}$ & $1 \times 10^{-9}$ & $1 \times 10^{-10}$ \\
Sample 4 & $1 \times 10^{-11}$ & $1 \times 10^{-8}$ & $1 \times 10^{-9}$ & $1 \times 10^{-10}$ & $1 \times 10^{-11}$ \\
\hline
\end{tabular}



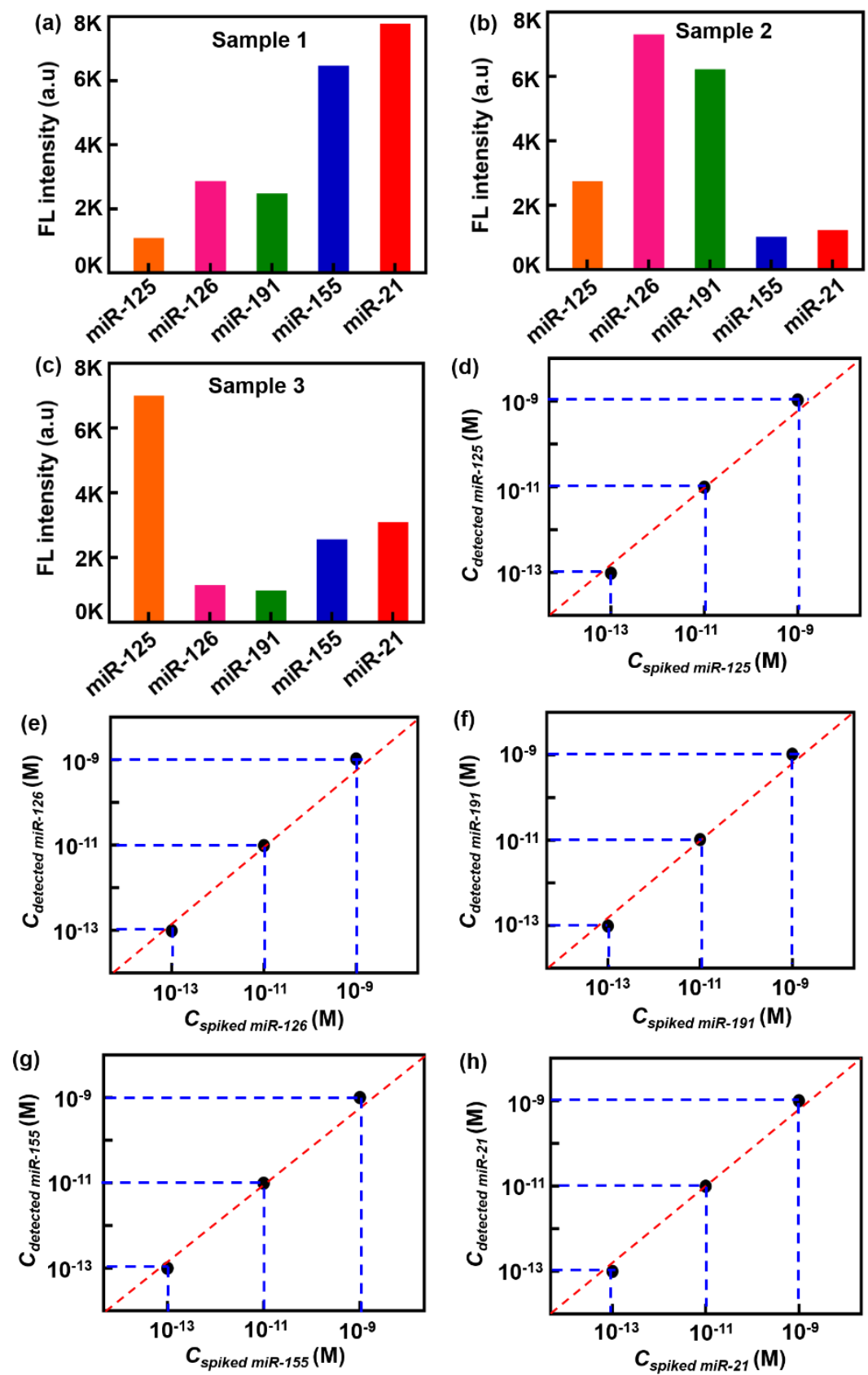

Figure S11. Detection of miRNA spiked in TE buffer. The actual detection results of spiked miRNAs with different concentrations in TE buffer according to (a) sample 1, (b) sample 2 and (c) sample 3. The deviation between theoretical concentration and actual detection concentration of each miRNA in TE buffer are presented as for (d) miR-125, (e) miR-126 (f) miR-191, (g) miR-155, and (h) miR-21. The concentration of each miRNA in each sample is shown in Table S2. The concentration of five DNA probe was $10^{-4} \mathrm{M}$. 

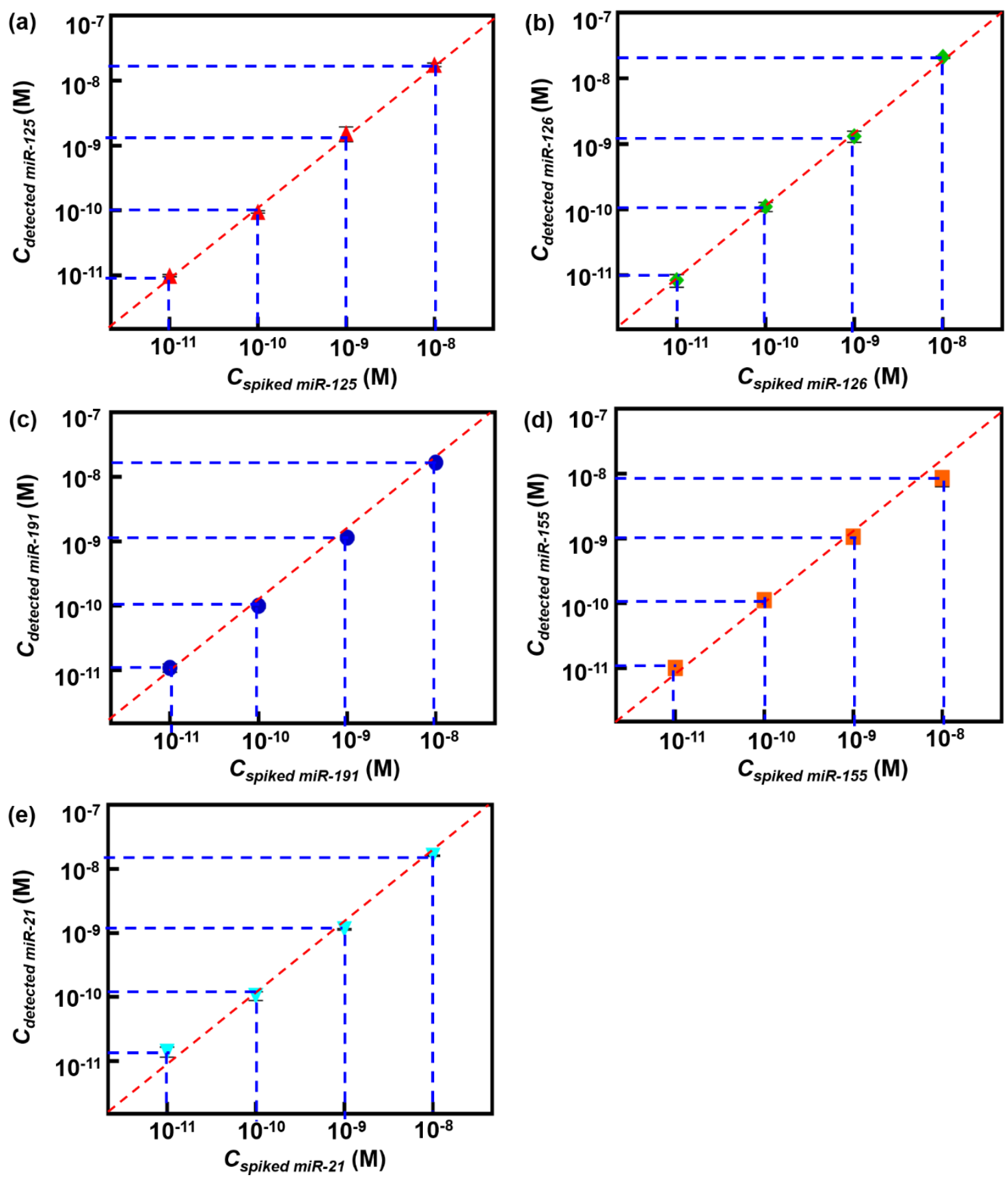

Figure S12. Experimental results of spiked miRNAs in serum samples as listed in Table S5. The correlation of spiked miRNAs concentrations and detected miRNAs concentrations: (a) miR-125, (b) miR-126, (c) miR-191, (d) miR-155, and (e) miR-21. Note: Each samples were tested 3 times, and error bars are the difference between mean value and standard deviation, which are derived from equation $\sqrt{\frac{1}{N} \sum_{i=1}^{N}\left(x_{i}-M e a n\right)^{2}}, \mathrm{~N}=3$. 
Table S6. The recovery percent of the actual detection miRNA concentration in TE buffer and serum.

\begin{tabular}{ccc}
\hline miRNA & Recovery percent (TE buffer) & Recovery percent (serum) \\
\hline miR-125 & $96.7 \%-106.2 \%$ & $97.9 \%-104.3 \%$ \\
miR-126 & $96.7 \%-104.7 \%$ & $101.4 \%-105.8 \%$ \\
miR-191 & $97.8 \%-104.7 \%$ & $96.5 \%-105.2 \%$ \\
miR-21 & $98.2 \%-101.2 \%$ & $102.4 \%-104.2 \%$ \\
\hline
\end{tabular}


Table S7. The miRNA actual detected concentrations and relative deviations of each sample in TE buffer, corresponding to Figure S11d-h.

\begin{tabular}{cccccc}
\hline & miR-125 & miR-126 & miR-191 & miR-155 & miR-21 \\
\hline $\begin{array}{c}\text { actual concentration } \\
(\mathrm{M})\end{array}$ & $1.062 \times 10^{-9}$ & $1.047 \times 10^{-9}$ & $1.047 \times 10^{-9}$ & $1.012 \times 10^{-9}$ & $1.011 \times 10^{-9}$ \\
$\begin{array}{c}\text { relative deviation (\%) } \\
\text { actual concentration } \\
(\mathrm{M})\end{array}$ & $6.2 \%$ & $4.7 \%$ & $4.7 \%$ & $1.2 \%$ & $1.1 \%$ \\
$\begin{array}{c}\text { (elative deviation (\%) } \\
\text { actual concentration } \\
(\mathrm{M})\end{array}$ & $2.1 \%$ & $3.3 \%$ & $3.9 \%$ & $2.9 \%$ & $0.7 \%$ \\
& $9.664 \times 10^{-14}$ & $9.735 \times 10^{-14}$ & $9.785 \times 10^{-14}$ & $9.937 \times 10^{-13}$ & $9.908 \times 10^{-14}$ \\
relative deviation $(\%)$ & $3.4 \%$ & $2.7 \%$ & $2.9 \%$ & $0.7 \%$ & $0.9 \%$ \\
\hline
\end{tabular}


Table S8. The relative deviation between the actual detection concentration and theoretical concentration spiked in serum, corresponding to Figure 6b.

\begin{tabular}{|c|c|c|c|c|c|}
\hline & miR-125 & miR-126 & miR-191 & miR-155 & miR-21 \\
\hline $\begin{array}{c}\text { actual } \\
\text { concentration }(\mathrm{M})\end{array}$ & $1.023 \times 10^{-8}$ & $1.058 \times 10^{-8}$ & $1.041 \times 10^{-8}$ & $1.024 \times 10^{-8}$ & $9.842 \times 10^{-8}$ \\
\hline $\begin{array}{l}\text { relative deviation } \\
(\%)\end{array}$ & $2.3 \%$ & $5.8 \%$ & $4.1 \%$ & $2.4 \%$ & $1.6 \%$ \\
\hline $\begin{array}{c}\text { actual } \\
\text { concentration }(\mathrm{M})\end{array}$ & $1.043 \times 10^{-9}$ & $1.014 \times 10^{-9}$ & $1.052 \times 10^{-9}$ & $1.042 \times 10^{-9}$ & $1.050 \times 10^{-9}$ \\
\hline $\begin{array}{l}\text { relative deviation } \\
\qquad(\%)\end{array}$ & $4.3 \%$ & $1.4 \%$ & $5.2 \%$ & $4.2 \%$ & $5.0 \%$ \\
\hline $\begin{array}{c}\text { actual } \\
\text { concentration }(\mathrm{M})\end{array}$ & $9.794 \times 10^{-11}$ & $1.056 \times 10^{-10}$ & $9.652 \times 10^{-10}$ & $1.025 \times 10^{-10}$ & $1.025 \times 10^{-10}$ \\
\hline $\begin{array}{l}\text { relative deviation } \\
(\%)\end{array}$ & $2.1 \%$ & $5.6 \%$ & $3.5 \%$ & $2.5 \%$ & $2.5 \%$ \\
\hline $\begin{array}{c}\text { actual } \\
\text { concentration }(\mathrm{M})\end{array}$ & $1.014 \times 10^{-11}$ & $1.047 \times 10^{-11}$ & $1.011 \times 10^{-11}$ & $1.036 \times 10^{-11}$ & $1.003 \times 10^{-11}$ \\
\hline $\begin{array}{l}\text { relative deviation } \\
\qquad(\%)\end{array}$ & $1.4 \%$ & $4.7 \%$ & $1.1 \%$ & $3.6 \%$ & $0.3 \%$ \\
\hline
\end{tabular}



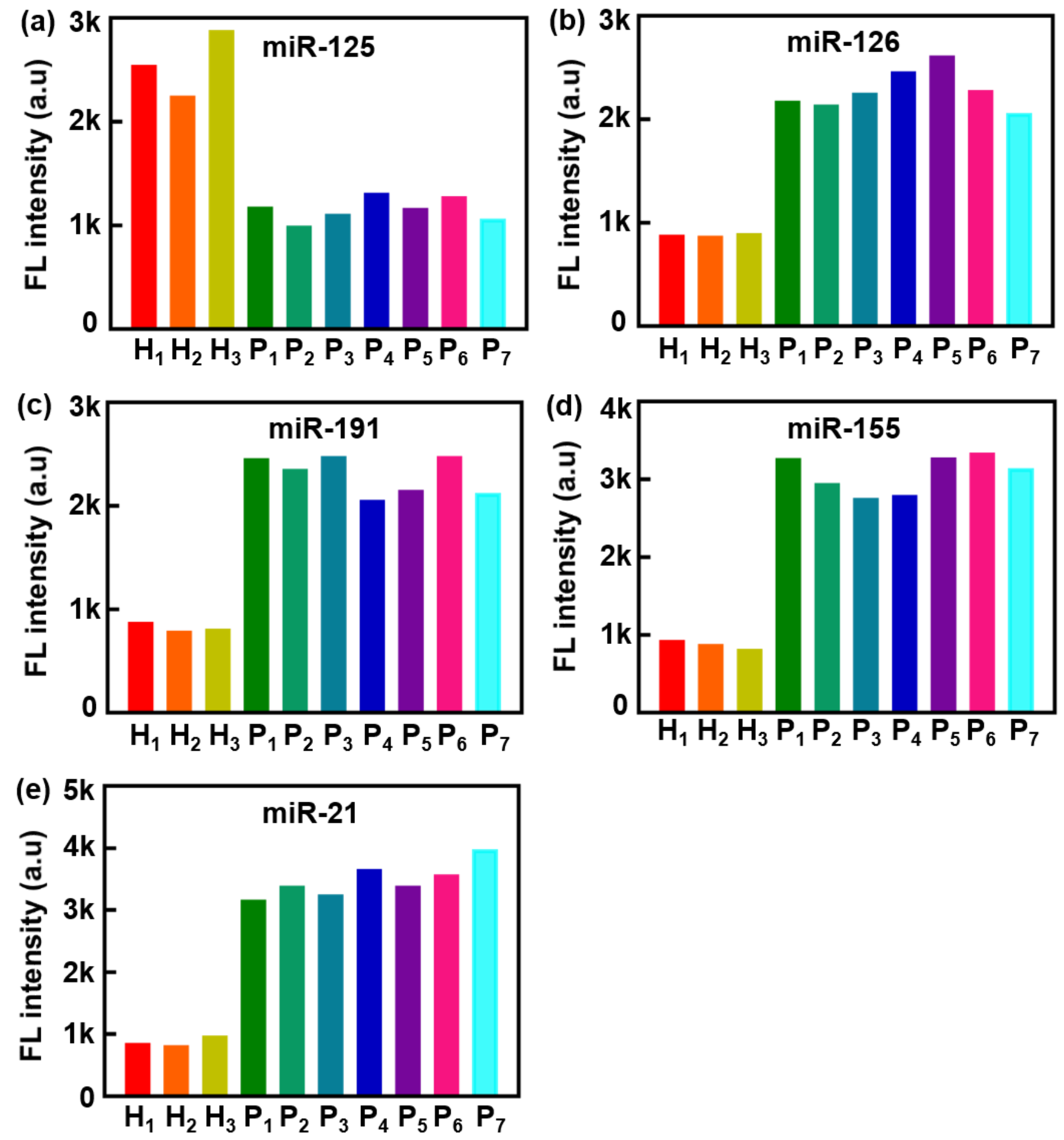

Figure S13. Detected fluorescence intensity of miRNA in healthy and patient serum. (a) miR-125, (b) miR-126, (c) miR-191, (d) miR-155, and (e) miR-21. H1-H3 are from healthy serum samples, and P1-P7 are from patients serum samples. 

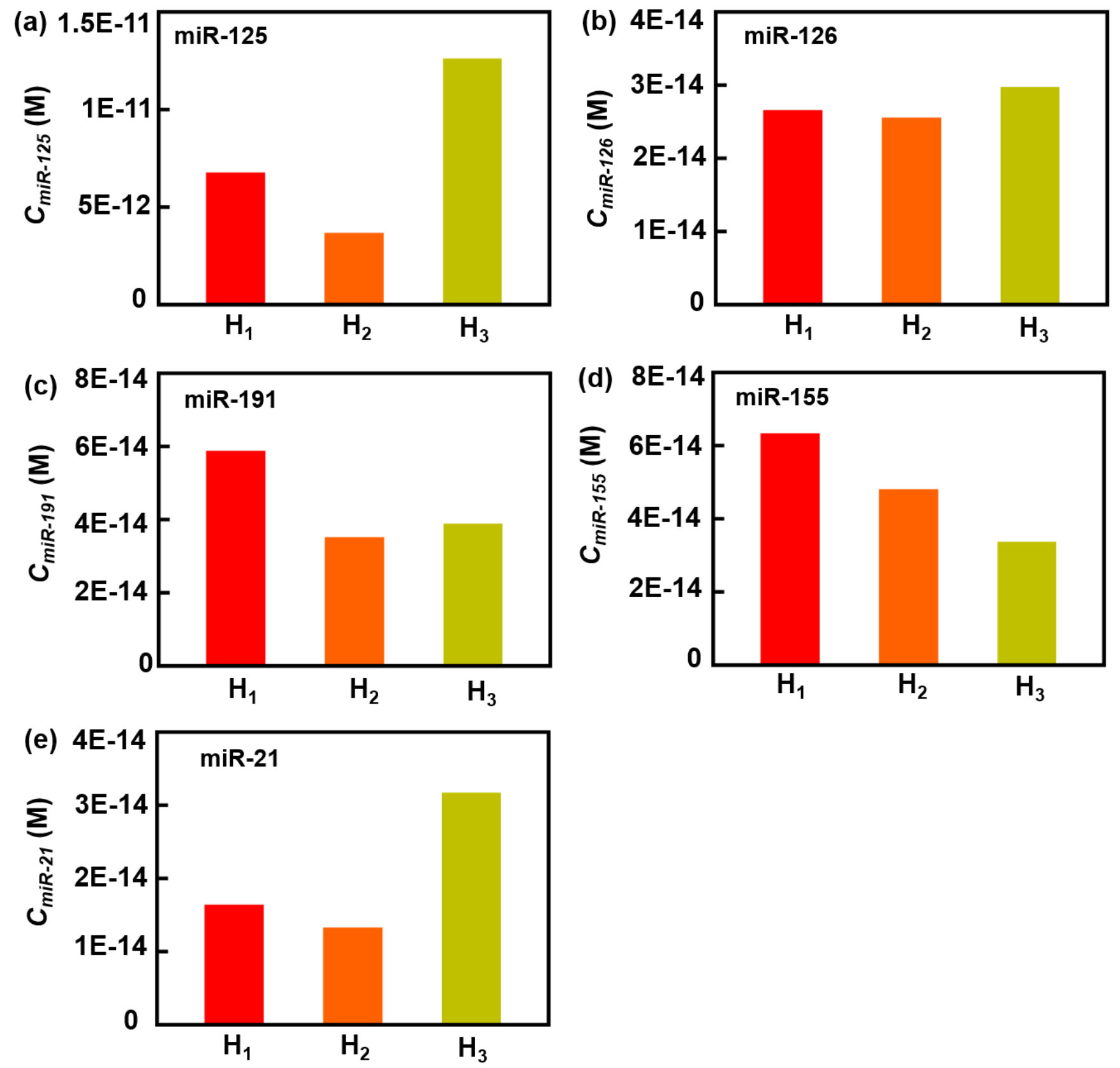

Figure S14. Detected concentrations of the miRNA biomarkers in serum samples from healthy persons: (a) miR-125, (b) miR-126, (c) miR-191, (d) miR-155, and (e) miR-21. Note, the concentrations of the miRNA biomarkers are calculated from the equations in Figure 3. 

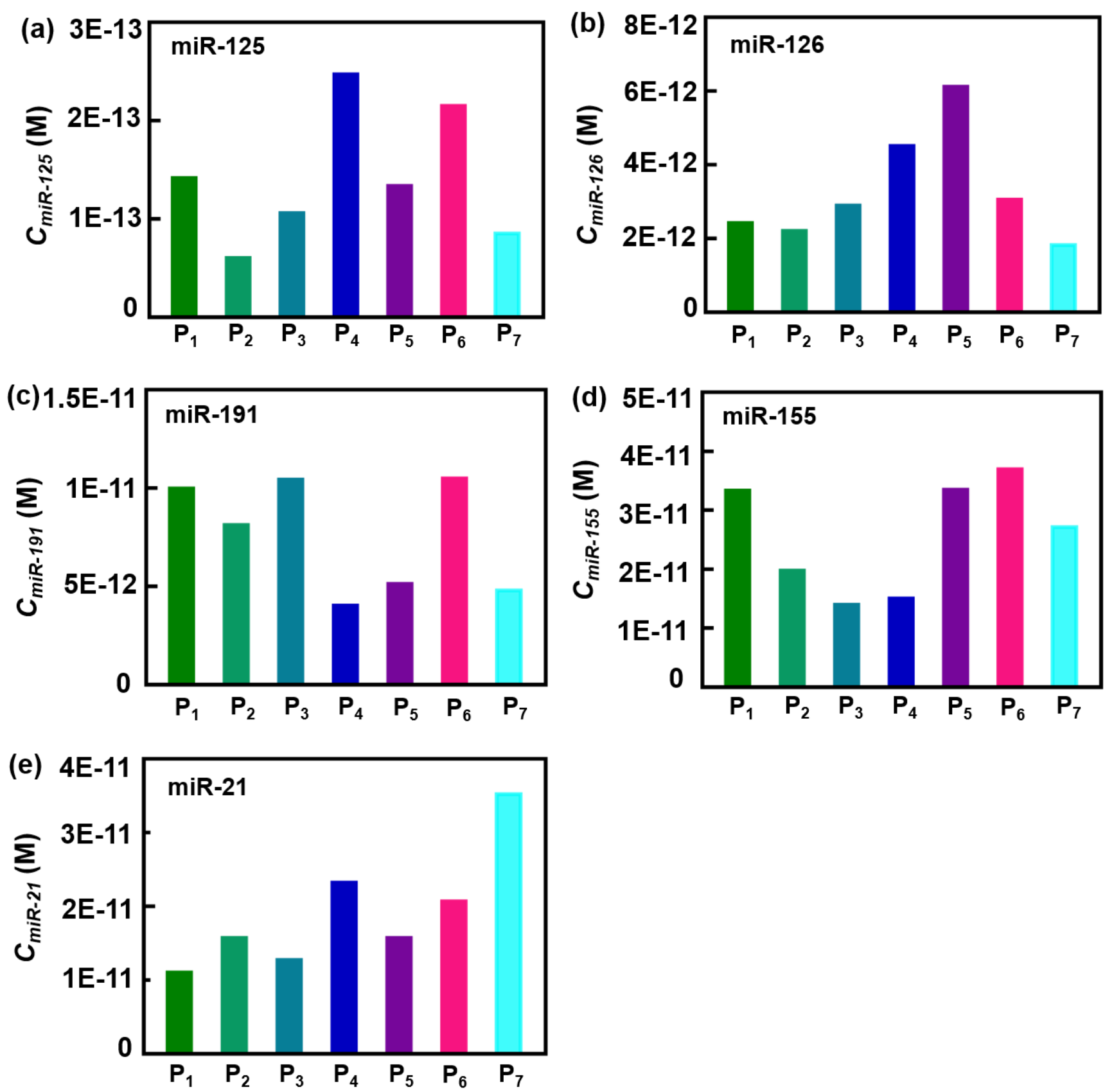

Figure S15. Detected concentrations of the miRNA biomarkers in serum samples from breast cancer patients: (a) miR-125, (b) miR-126, (c) miR-191, (d) miR-155, and (e) miR-21, Note, the concentrations of the miRNA biomarkers are calculated from the equations in Figure 3. 
- References

(1) Zhang, W. C.; Chin, T. M.; Yang, H.; Nga, M. E.; Lunny, D. P.; Lim, E.K. H.; Sun, L. L.; Pang, Y. H.; Leow, Y. N.; Malusay, S. R. Y.; Lim, P. X. H.; Lee, J. Z.; Tan, B. J. W.; Chang, N. S. E.; Lim, H.; Lim, W. T.; Tan, D. S. W.; Tan, E. H.; Tai, B. C.; Soo, R. A.; Tam, W. L.; Lim, B. Nat. Commun. 2016, 7, 11702117017.

(2) Kim, M. K.; Jung, S. B.; Kim, J. S.; Roh, M. S.; Lee, J. H.; Lee, E. H.; Lee, H. W. Virchows Archiv 2014, 465, 463-471.

(3) Prislei, S.; Martinelli, E.; Mariani, M.; Raspaglio, G.; Sieber, S.; Ferrandina, G.; Shahabi, S.; Scambia, G.; Ferlini, C. BMC Cancer 2013, 13, 72-85.

(4) Chung, Y. W.; Bae, H. S.; Song, J. Y.; Lee, J. K.; Lee, N. W.; Kim, T.; Lee, K. W. International Journal of Gynecologic Cancer 2013, 23, 673-679.

(5) Xu, X.; Ban, Y.; Zhao, Z.; Pan, Q.; Zou, J. Aging (Albany NY) 2020, 12, 7761-7773.

(6) Liu, X.; Ju, J.; Liu, Q.; Zhu, Z.; Liu, C. Cancer Manag Res 2020, 12, 5677-5687.

(7) Pouladi, N.; Kouhsari, S.; Feizi, M.; Ravanbakhsh, R.; Azarfam, P. Asian Pacific journal of cancer prevention : APJCP 2013, 14, 3503-3507.

(8) Zhang, K.; Zhao, S.; Wang, Q.; Yang, H. S.; Zhu, J.; Ma, R. Annals of Surgical Oncology 2015, 22, 536-544.

(9) Azimzadeh, M.; Rahaie, M.; Nasirizadeh, N.; Ashtari, K.; Naderi-Manesh, H. Biosens Bioelectron 2016, 77, 99-106.

(10) Chand, R.; Ramalingam, S.; Neethirajan, S. Nanoscale 2018, 10, 8217-8225.

(11) He, M. Q.; Chen, S.; Yao, K.; Wang, K.; Yu, Y. L.; Wang, J. H. J. S. M. Small methods 2019, 3, 1900017-1900023.

(12) Hwang, M. T.; Heiranian, M.; Kim, Y.; You, S.; Leem, J.; Taqieddin, A.; Faramarzi, V.; Jing, Y.; Park, I.; van der Zande, A. M.; Nam, S.; Aluru, N. R.; Bashir, R. Nat Commun. 2020, 11, 1543-1554.

(13) Shamsi, M. H.; Choi, K.; Ng, A. H.; Chamberlain, M. D.; Wheeler, A. R. Biosens Bioelectron 2016, $77,845-852$.

(14) Cheng, H. L.; Fu, C. Y.; Kuo, W. C.; Chen, Y. W.; Chen, Y. S.; Lee, Y. M.; Li, K. H.; Chen, C.; Ma, H. P.; Huang, P. C.; Wang, Y. L.; Lee, G. B. Lab Chip 2018, 18, 2917-2925. 